\title{
Fair or Foul in Interracial Discourse
}

\section{Dan Subotnik}

Invited by the Diversity and Inclusion Committee, a black woman in her mid-forties recently came online to my law school to talk about microaggressions. The presenter, an experienced speaker on this topic, is also an attorney. Since more and more such speakers (including Asian Americans and Hispanic Americans) are being invited to our schools every day, it seems important for academics to get some sense of the methods, goals, and effects of these anti-racism programs as they actually play out on the American campus.

Speaking about people of color-and mostly to whites-the presenter defined microaggressions as “reminders that you don't belong, you are less than, that you are not worthy of the same respect that white people are afforded." Because that message works great harm in normalizing anti-black racism, microaggressions, she went on, need to be recognized, faced frontally, and put to an end. In the meantime, we need to understand, what counts is not the motive for an alleged microaggressive comment, but rather how the remark "lands on" its recipient.

To illustrate, the speaker offered, it is hurtful for a black woman to be asked why she is angry or for an Asian American to be asked where he is from; these questions thus cross the discursive line. In the former case, the question is likely to land heavily on its target because, playing on a stereotype of the angry black woman, it could make her believe that anything she said would be doubted, or worse, dismissed. In the latter case, the question will have a similar effect because it implies that the target is an outsider, not a (real) American.

Black people, likewise, should not be asked how they got their jobs: inquirers may be fishing for affirmative action as the answer so as to buttress their own feelings of superiority. As just suggested, the actual motive for such a question-perhaps to figure out how to get a job oneself-is not important. When

Dan Subotnik is Professor of Law at the Jacob D. Fuchsberg Law Center at Touro College Central Islip, New York; dans@tourolaw.edu. He is the author of Toxic Diversity: Race, Gender, and Law Talk in America (NYU Press, 2005), among other works. Subotnik's "Race and Gender as Job Qualifications," appeared in our Winter 2019 issue. 
they violate these rules, the speaker insisted, offenders need to, in some public way, "apologize” and "promise to do better.” Black people, in sharp contrast, are permitted, indeed encouraged, to express themselves freely.

Given her argument, the speaker could hardly have adopted an overtly angry tone; and, indeed, she explicitly disavowed anger. As I saw it, however, her slow, deliberate, stern, and highly self-assured delivery was reminiscent of an adult talking down to a young child. Perhaps this is why no one felt impelled to ask the forbidden question.

Query: how is a skeptical listener to respond to a message such as the speaker's? Asking one who projects strong discontent with the status quo, "Why are you angry?"-not as a rhetorical but as an informational question-will lead to the questioner being discounted as too unfeeling or ignorant, at a university no less, to merit a response. And yet, the question would not fit the above definition of a microaggression in that it is not tantamount to saying that a black woman “doesn't belong” or “is not worthy of respect.” Productive discourse, whether in politics or otherwise, often entails charged give and take. A good many people who are admittedly angry, moreover, speak up confidently, even enthusiastically, about the roots of their anger. This seems especially true of critical race theorists, who seem thrilled to unburden themselves. If personal questions by whites are not necessarily hurtful, and if, as the speaker herself insisted, black women's views are not monolithic, does it make sense to shut down whites who are eager to learn something and perhaps to promote racial understanding?

I speak with greater personal experience and self-assurance on the national origin issue, and this has led me to conclude, happily, that white people are not as dishonorable, and people of color are not as fragile, or quick to take offense, as the speaker suggested. To start, "Where are you really from” is likely to arise, let me posit, not from animus toward the "other," but from the known (and perhaps forgivable) inability of Americans from many homogeneous groups to readily distinguish among Chinese, Japanese, and Korean features and, often, accents, "Where are you from?" is surely less intrusive as to social status, than the American standard, "What do you do?"

To more fully make my case, here is some autobiographical detail. I grew up speaking a foreign language at home and have studied foreign languages and the dictions associated therewith all my life, much like Henry Higgins ("My Fair Lady"), but without the swagger. Sometimes when I've heard something unusual in people's speech, be they from Asia, South America, or otherwise, I have asked 
them where they are from. They may have been momentarily nonplussed-a moment of microaggression?-but no one, as I can recall, has ever taken my inquiry amiss; my interlocutors have known full well that their speech is recognizably different from, say, Joe Biden's. Sure, my interlocutors may have repressed the "injury," but I have looked carefully for signs of discomfort and have found none.

Occasionally, I go further. Sometimes when a person with a Spanish accent addresses me in English and I have no reason to suppose that my response will be badly received-say, on the ground that I suspect that my interlocutor cannot speak English easily-I will respond in Spanish. Here again, I have witnessed no discomfort, and I am confident in attributing my behavior to my having been a Spanish literature major in college, one who now enjoys exercising underused language muscles. I trust, moreover, that speaking Spanish bespeaks my commitment to cultural pluralism, of which I am a strong advocate. I sometimes also switch into Spanish, I admit, because I want to test and display my skill before a native speaker. As to this last motive, I claim no virtue; but neither do I admit to any fault.

What I am also attempting in most instances is to connect with people in a distinctive, personal way. A year ago, for example, I responded in such a way both to a student and to my new Cuban-American doctor with no resultant bristling from either; indeed, the latter switched instantly to Spanish. In addition, I volunteered to a completely fluent English-speaking faculty colleague that I can pick up faint traces of his native Spanish language. (“Example” came out EXX-ample, not EGGS-ample.) I knew there was some risk in saying it, but I was not deterred. As I suspected and hoped, rather than being offended by my presumptuousness in "othering" them, my interlocutors invariably seemed pleased by my efforts to connect with them in their native languages and to carefully engage with their speech.

So, then, are minorities generally less sensitive and more resilient-perhaps far more resilient-than the microaggression theorist admits? A new article by a legal scholar and a psychologist suggests that some of the tactics found in diversity training and theory reflect political strategies rather than true emotional sensitivities. Microaggression theory, they believe, utilizes the gloss of scientific method to validate the "ideological hunches" of its practitioners and that "nobody-neither diversity administrators, academics, or 
journalists—should take currently propagated lists of microaggressions as representative of anything meaningful."1

Keeping an open mind, what should we do about the countervailing positions here-my view that questioning a person of color on race issues is not necessarily hurtful as claimed, but rather, like my language games, is morally permissible, and the presenter's view that it is not? No moral system, of course, can allow people to be the final arbiters in their own cases. And the strong possibility that the speaker might have allowed me to respond frankly and comprehensively to a hypothetical angry white woman does not automatically mean that I am free to do the same to her, a black woman. Although the speaker did not explicitly address this point, she would likely say that whites have always enjoyed a position of privilege in relation to blacks, and therefore questioning a black woman in this manner serves only to sustain an unequal distribution of power.

But even if it were true that white men have always held power over black women and that questioning a black woman about race perpetuates that inequality, does that justify the claims and arguments that the speaker made? Probably not. First, women today, and perhaps black women most of all, are not nearly as weak in relation to white men as the speaker and others suggest. Indeed, critic Meghan Daum has written-precisely as the speaker illustrated through her talk-that women today, presumably including black women, have the extraordinary power to just "shut down a conversation [about gender] by citing male privilege.”2 Second, all people-men included-have fundamental rights: "If liberty means anything at all," George Orwell submitted, "it means the right to tell people what they do not want to hear." ${ }^{3}$ Third, the speaker's words in fact landed hard on me, so hard that they galvanized me to write this essay. Many people surely would bridle at a charge, however camouflaged, that they have racist hearts. Fourth, yes, as the speaker suggested, tact is called for in social discourse and that requires knowing something about the person you are talking to; but if whites are not allowed to ask non-white speakers, even politely, why they are saying the things they are, there would seem to be no way to get necessary information.

1 Edward Cantu, Lee Jussim, "Microaggressions, Questionable Science, and Free Speech," SSRN-id3822628.pdf at 43 .

2 Meghan Daum, The Problem with Everything: My Journey Through the New Culture Wars (Gallery Books, 2019), 84.

3 George Orwell, "Freedom of the Press," New York Times, Oct. 8, 1972, https://www.nytimes. com/1972/10/08/archives/the-freedom-of-the-press-orwell.html. 
Writ large, tact must, within limits, often give way to the right to speak freely. That is no doubt why, for most law professors and undoubtedly many others, free speech, not tact, is the cornerstone of our political culture. As the law recognizes in its own domain, there must be a compelling need for prior restraint on any speech.

I wanted badly to talk (back) to the speaker about these matters, to point out what I found grating and unproductively self-righteous. If by chance, she was just trying to get over on her audience, as I have sometimes thought, I wanted her to know that I had not been had. But even after (or because of?) forty years of teaching law, I confess-with no little embarrassment-that I worried about her likely reply. Would she call me out for a microaggression and demand an apology?

Though in no way blaming my colleagues in the audience, I am quite certain that if even just one of them had spoken up, I would have felt differently. In retrospect, it seems amazing to me that professors zealously training students to zealously defend clients apparently felt no need to stand up for themselves, even to argue extenuating circumstances. What kind of message would just rolling over send to students about the competence of faculty?

There was another-and surely my most important-reason for lying low. If I challenged the presenter publicly, my students and colleagues in the audience might, trigger-fingered as some are, label me a racist. This is surely no paranoid fear on my part; many of us have by now read accounts of innocent culture war victims. And indeed, in an era when those who are not actively "antiracist" are "racist," or in which "silence is violence," such accounts are to be expected. Having poisonous relationships with people I like, and regularly work alongside at school, would be no trivial matter; but beyond that, cancel culture has recently worked to actually scotch the careers of a number of academics on what appear to be spurious charges of race insensitivity. Even this faculty member, now nearing the end of his career, was not prepared to blow himself up to hasten that end.

Following news events of recent months-and mindful of the strong calls for standing up to what amounts to bullying offered in such literary sources as the dramas Rhinoceros and The Crucible-I have come to the conclusion that if those accused-including even the tenured-are too timid to speak, charges of racism will likely escalate in number and scope. A refusal to challenge one 
claim of microaggression, that is, will lower the barrier for other, ever wider such claims, giving way to increasing efforts to silence white voices.

It seems fair to say that academics, like professionals in other high-achieving fields, often have insecurities about some aspect of their own training; for faculty of color, some of these insecurities, one can imagine, may well be the products of racism. Is it farfetched to predict the next issue in the microaggression story? Will it soon be an official microaggression for a white academic to ask a black colleague if he has ever read, say, Pride and Prejudice, Huckleberry Finn, or The Bluest Eye?

The "diversity training" I received was optional. Given the current state of race relations, should we expect calls for compulsory anti-microaggression training directed at students and faculty? Boasting of their diversity efforts, quite a few schools have already done just that for students; more are seriously considering it. One hundred and fifty law school deans have petitioned the American Bar Association to embrace mandatory diversity training for students. At least one law school already mandates such training for faculty (The University of Missouri-Kansas City Law School). If the time for mandatory training for students has come, can mandatory training for faculty be far behind? How else, after all, can schools be confident that perceptive students will not ridicule or sabotage such training upon learning that their professors, at least some of whom they admire, remain untrained?

Academics know too well that the most pathological political groups in recent times, whether dominant or not, have attempted to suppress speech in an effort to control discourse. It seems no exaggeration to say that we need to stay alert and at least accept the possibility that suppressing white speech is far from peripheral to diversity training plans. This goal is certainly important for Professor Meera Deo. ${ }^{4}$ Early in her book (which I am currently reviewing for a law review), she tries to preempt the white male responses she anticipates not by positing and then refuting them point by point, but by attempting to preempt them by labelling them as "Manspeaking, Hepeating, and Whitesplaining."

A step back is needed now. The speaker was in essence formalizing the rule of difference now in effect for blacks and whites in race discussions, a rule that allows blacks to call out whites for Whitesplaining, while forbidding whites

4 Meera E. Deo, Unequal Profession: Race and Gender in Legal Academia (Stanford University Press, 2019), 43. See my review "Race and Gender as Job Qualifications," Academic Questions (Winter 2019).

5 Ibid. 
from testing the charge by bringing up Blacksplaining. There is nothing new in proposing disparate standards based on power differentials, but it does raise some important questions. Do the grim parts of our racial history require us to dispense with rules of behavior that bind us all? Are blacks and whites so differently situated that giving black women what is in effect a Heckler's Veto on race issues fair and productive? Or will that dispensation in the end impede, and even undo, social progress? More specifically: (1) If whites are discouraged from questioning black writers on their anger; (2) if it is bad form to ask black colleagues how they got their jobs; and (3) if white talk is continuously presumed to be hostile, thus requiring whites to mince their words, how will we ever be able to understand our colleagues and reach congenial understanding in a world where words are unavoidable carriers of communicative content and meanings are subjective? This is not to say that truly abusive race talk should ever be welcomed (assuming the terms "white" and "abusive" continue to remain distinguishable).

It would be helpful, though not necessarily dispositive, to have a demographic sense of stakeholder sentiments about interracial (and intergender) speech. Are the speaker's findings reliable? Is there a consensus among people of color in this area? Alas, the presenter offered no such information (any more than she pointed to empirical evidence about whites as a group). Which raises the question: Since it directly challenges the speaker's teachings, is the retort embodied in this essay itself a microaggression, requiring a mea culpa?

One does not have to be white to have a robust answer to these questions. Deeply troubled by America's unproductive race talk, black Harvard professor of sociology Orlando Patterson, an eminent and lifelong student of race relations, needs to be heard here. In his view, people in general and black people in particular are hardier and more resilient than microaggression theory assumes and that it is actually healthy for black people to be exposed to a wide range of challenging opinion. As for their own interracial speech, black people should understand that a group's goals need to be balanced against a more general goal, common to us all: sharing the same territory peaceably with all our compatriots. And that goal can be attained only when we all give voice to our thoughts. The underlying problem today, encapsulated by Patterson, is that 
"no European-American person, except one insensitive to the charge of racism, dares say what he or she really means." ${ }^{6}$

Patterson's stunning assessment of our condition, which few academics would publicly embrace, leads to the conclusion that we need to worry less about hurt feelings, our own or others. We need to speak our piece more and encourage others to speak theirs. This would obviate the need for a new media outlet such as The Journal of Controversial Ideas, which advertises itself these days as a platform for publishing articles anonymously; and it would undercut any argument that the Diversity Committee should serve as prosecutor, judge, and jury-in a word, as censors.

Patterson understands that it is actually a strength of traditional American culture that it gives wide berth to academics who, just like our microaggression speaker, press uncomfortable positions. Thus, Patterson instructs, “AfroAmerican and Euro-American people should treat one another exactly alike: as responsible moral agents. We do not need any special sets of sensitivities."

Risky? Maybe so. But judging by current public and social media content, interracial trust today is dangerously low and sinking. New approaches seem timely. There can be no guarantees, of course, but "if engagement is the first step in healing," as black emeritus Yale Law professor and Episcopal Priest Harlon Dalton has written-offering us all words that can serve as a working motto- "then the second is pure, unadulterated struggle. . . We will never achieve racial healing if we do not confront one another, take risks... say all the things we are not supposed to say in mixed company." 8

All of which brings us back to our speaker's goal of garnering for black women "the same respect as white people are afforded." But in the world that I know, you don't earn respect from telling people not to disrespect you. You get it, rather, from demonstrating competence and moral agency in the sometimes messy interaction of normal human affairs.

\footnotetext{
6 Orlando Patterson, The Ordeal of Integration: Progress And Resentment In America's "Racial" Crisis (Basic Civitas Books, 1998), 40.

7 Ibid.,115.

8 Harlon Dalton, Racial Healing: Confronting the Fear Between Blacks \& Whites (Anchor, 1996), 97, 4.
} 